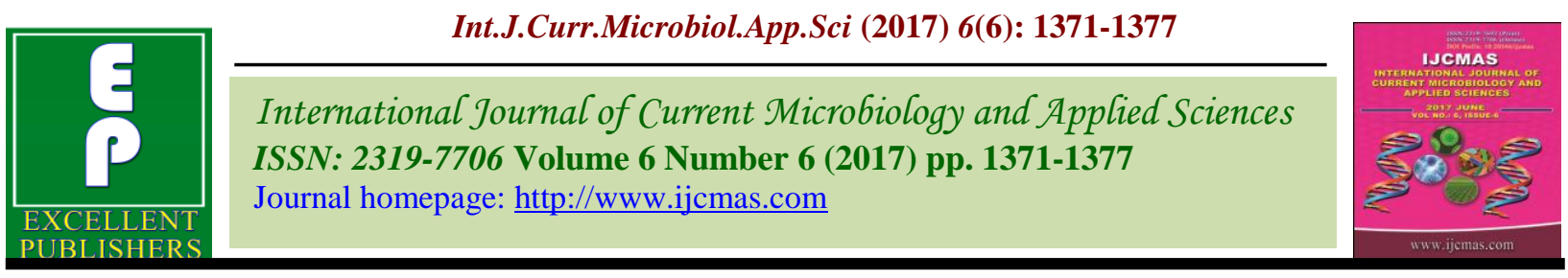

Original Research Article

https://doi.org/10.20546/ijcmas.2017.606.161

\title{
Socio-Cultural Paradigm of Agroforestry in India
}

\author{
Yogesh Kumar ${ }^{1}$, Tarun Kumar Thakur ${ }^{2 *}$ and A. Thakur ${ }^{3}$ \\ Department of Environmental Science, IG National Tribal University, \\ Amarkantak, MP- 484887, India \\ *Corresponding author
}

Keywords

Hot spot,

Sustainability, Alley

cropping, Home

garden and Average

land holding.

Article Info

Accepted:

19 May 2017

Available Online:

10 June 2017

\section{A B S T R A C T}

In India, major Agroforestry systems are estimated to cover 25.32 million ha. That is approximate $8.32 \%$ of total geographic area of country. Agrosilviculture practice includes alley cropping, multiple cropping and inters cropping. Aquasilvicultures, e.g. tree-fish-arable crop and tree-fish-livestock systems, are alternatives for land use in the wetlands. Agri-Silvopastoral systems are popular in the southern region (Home garden in Kerala). However, compared to a monoculture, well-managed systems have many benefits but particular system not popularized at large scale in country. The major constraint on Agroforestry is that lack of proper management, shortage of technical support, rigid policy of harvesting of tree products and informal, unstructured market. Due to these reason farmers are disappointing to grow tree on their field resultant that the principle of Agroforestry are not applied at large scale in country. However, there is a great potential for the development of Agroforestry in India. This paper presents recommendations concerning policy options, technical support, extension, and marketing in Agroforestry.

\section{Introduction}

India is a country in South Asia. It is the seventh largest country area wise and according to population it have second place in the world (with 1.2 billion people). India lies between north $8^{0} 4^{\prime}-37^{0} 6^{\prime}$ to east $68^{0} 7$ $97^{0} 25^{\prime}$. India lies within the indomalaya ecozone and it does contain two biodiversity hotspots in the world (ZSI, 2012). The climatic condition of India has very diverse in nature due to this, country considered like subcontinent in nature. There is a vast opportunity for agriculture and other farming practices. Apart from agriculture, farmer of country practices some other farming practices like dairy farming, poultry farming, piggery farming, Horticulture, Aquaculture, and Agroforestry. Out of these farming practices Agroforestry practices have vast potential, multiple uses and source of sustainable livelihood for a country have huge population pressure like India. Agroforestry is single and unique in many respects. It covers both science and practices. With respect to science it helps to solve many question arise in farmers' mind, when they adopt agroforestry system on their field. The question like, which tree + crop combination is suitable on which type land? Which system is best suitable for concerned farmer? While, practices of Agroforestry deals with use of 
different type of land use system, cultivation practices like Alley cropping, multiple cropping, home garden etc. But if we see the opportunity for the application of Agroforestry principle in the develop country like in India, either this system indigenously exist on rural poor farmers land or some progressive farmer adopt the principle of Agroforestry system. Very rarely these farming practices are adopted in large scale except in some cases like poplar and eucalyptus based Agroforestry system, the reason behind that these tree species are fast growing and provide early return to concerned farmer. Agroforestry practice in India is old and traditional. Some systems have been researched since the late 19th century and there has been research on fodder-fuel plantations since the 1950's. Different Agroforestry practices in India under different agro-ecological regions arc described here with research results. It is concluded that there are areas several of research on Agroforestry)' yet to be untouched. The system still needs greater research and management. The challenges and opportunities for improvement are vast (Solanki et al., 1998). Agroforestry practices have lack of management, lack of technical support, government policies etc. are the main constraint that make the system unsuitable to farmers. However, there is a great potential for the development of Agroforestry in India. For this there is urgent need of modification in policies and rule of government, Technical support to farmers and well defined market structure are some possible way that attracts the farmer's attention towards Agroforestry practices. There are many other socio-cultural considerations like labor shortage, average land holding, and awareness or farmers perception, also play an important role in restriction of Agroforestry practices in country. The current study is focused on the issues that restricted the expansion of Agroforestry in country and also compare the
Agroforestry practices between world and India. The total area under Agroforestry in world is 1023 million hectare (FAO 2000). Out of this, the maximum area under Agroforestry, reported in South America followed by sub Saharan Africa. However the area under Agroforestry is increasing continuously, example in India, in 2007 it is reported 7.4 million hectare (Zomer et al., 2007) but in 2013 it reached up to 25.32 million hectare (Dhyani et al., 2013).

\section{Materials and Methods}

The current study overview on the present status of Agroforestry in country and also find constraint and sociocultural consideration that hesitates farmers to adopt Agroforestry principle in India at large scale:

\section{Land holding pattern in India}

Total operated area in India is $\mathbf{1 5 9 . 5 9}$ million ha which decrease very drastically because populations of country increase continuously is depicted in table 1 .

The average size of land holding in India is 1.55 hectare which very less in comparison of world average. The number of Medium \& Large holdings account for less than 5\%, they make up for close to $1 / 3^{\text {rd }}$ of the total area under operation and remaining $2 / 3$ area falls under the category of small and marginal farmer. These small and marginal farmer even not able to subsistence their family by growing crop on concerned land. So there is a no question to grow any crop rather than basic crop (grain crop).

\section{Shortage of skill labor}

First thing, Almost all Agroforestry practices demand changes in the labor practices of farming system in to which they are worked earlier(agriculture, plantation etc.). Labor 
requirement are secondly, the labor shortage are seen as sharp reduction in the area of land cultivated and a shift from cash to food crops.

Third, the agricultural work and Agroforestry work lapse at a sometime during a year. For example planting of tree in rainy, huge demand of labor in alley cropping during busiest time of the year that is rainy season, these all the reason affect the smoothness of Agroforestry system in Indian condition.

Market problem of agroforestry products specially forest produce

Forest \& forestry products viewed as being outside the main stream of agriculture \& agriculture product. There is a well-defined rule regulation and better market facility for agriculture products. While in case of forest the market of forest products are informal and unstructured and there is lack of well-defined set and rule about marketing of Agroforestry products in India. There are only some tree which is exempted to felling like eucalyptus, poplar, and casuarinas etc. but for felling of others tree, a legal procedure should be followed while felling these trees. All these procedure make farmer hesitant to adopt this system. There is very instability about price of forest product or not based on real market assessment which make people to shift on alternatives material such as agriculture by product for fuel wood and biomass (Hoskins, 1987). These result disappointing farmers to integrate tree component on their field.

\section{Farmer's perception about agroforestry}

All most farmers think about tangible benefit and expect for early return like agriculture crop. They never bothered on intangible benefit long turn benefit. The farmers have common perception that tree component reduce the yield of agriculture crop or main crop in following way:
Tree component interfere with agriculture operation

Tree exhausts water and nutrient from field which is essential for main crop.

Tree is home of certain pest and insect which is harmful for concerned crop.

Tree provide shed which interfere the growth of agriculture crop.

They also have thought that planting of tree incurred extra cost. Majority of farmer's view that the Agroforestry systems would have no effect on farm income and increase their extra work and care for land (Matthews et al., 1993). These are common perception prevalent in farmer community about Agroforestry.

\section{Lack of research and extension activities in field of agroforestry}

Already established field of agriculture and there are many technology for improving the production. In Agroforestry, however, there are only a few research-validated technologies. Many promising Agroforestry technologies, whether found in existing farmers' practice or newly conceived by researchers, require considerably more research attention before they can confidently be recommended for wider adoption (ICRAF 1986). In Indian context, in this field the research began 1983 by the started as ICAR (Indian Council of Agriculture Research) with the help of All India Co-ordinated Research Project on Agroforestry (AICRAF). The National Research Centre for Agroforestry is establishment in 1988 of the, which has now been upgraded as the Central Agroforestry Research Institute (CAFRI, 2014), Jhansi. However, in India less concerned was given in the field of Agroforestry with respect to research and extension activities compare to 
agriculture. The major constraint on Agroforestry is that most of the system is on low level of management, primarily resulting from shortage of technical support (Haung et al., 1997). There is many KVK's running in country but these all are mainly concerned with agriculture activities. Unlike agriculture, in forestry either none field specific hybrid or variety invent or if invented it not reach up to farmer field. So the program LAB TO LAND had shown failure in case of forestry sector.
There is no doubt that some eminent scientist of forestry release or developed hybrid and variety in forestry sector but due to lack of extension activities this research or technology bound up to lab only. So there is a urgent need to open VAN VIGHYAN KENDRA as early as possible. There are some policies and mission is implemented by government of India and some institute also actively involved in research and extension activities related to Agroforestry.

Table.1 The operated area in country divided in following category

\begin{tabular}{|l|l|}
\hline Category & Operated Area \\
\hline Marginal Holdings & Below 1 Hectare \\
\hline Small Holdings & 1 to 2 Hectares \\
\hline Semi-Medium Holdings & 2 to 4 Hectares \\
\hline Medium Holdings & 4 to 10 Hectares \\
\hline Large Holdings & 10 Hectares and above \\
\hline
\end{tabular}

(Source: Agriculture census 2010-2011)

Table.2 The current status of Agroforestry in developed and developing countries

\begin{tabular}{|l|l|l|l|}
\hline Country & Area(M ha) & Specific information & Reference \\
\hline Indonesia & 2.8 & Jungle rubber Agroforestry & Wibava et al., (2006) \\
\hline Indonesia & 3.5 & All multistrata Agroforestry & $\begin{array}{l}\text { Van Noordwijk and } \\
\text { Ong (1999) }\end{array}$ \\
\hline India & 25.32 & National estimate & Dhyani et al., (2013) \\
\hline Nigeria & $5.0-6.0$ & Recently planted & $\begin{array}{l}\text { Gray } \\
\text { (pres.com) }\end{array}$ \\
\hline Mali & 5.1 & $90 \%$ of agriculture land & $\begin{array}{l}\text { Cisse, MI. (1995) } \\
\text { Boffa } \text { et al., (1999) }\end{array}$ \\
\hline $\begin{array}{l}\text { Central } \\
\text { America }\end{array}$ & 9.2 & Silvopastoral system & $\begin{array}{l}\text { Beer } \text { et al., (2000) } \\
\text { America }\end{array}$ \\
\hline $\begin{array}{l}\text { Spain/Portug } \\
\text { al }\end{array}$ & 6.0 & Coffee Agroforestry & Beer et al., (2000) \\
\hline $\begin{array}{l}\text { China } \\
\text { World wide }\end{array}$ & 7.8 & Dehasa Agroforestry & Gaspar et al., (2007) \\
\hline
\end{tabular}

Sources: IAASTD 2008. 
Table.3 Average size and fragmentation of agricultural holding

Continental wise during (1995-2005)

\begin{tabular}{|l|c|c|}
\hline $\begin{array}{l}\text { Countries by continent } \\
\text { (Number of reporting countries } \\
\text { is given in parenthesis) }\end{array}$ & $\begin{array}{l}\text { Average area per holding } \\
\text { (hectare) }\end{array}$ & $\begin{array}{l}\text { Average number of } \\
\text { parcels per holding }\end{array}$ \\
\hline World total & 5.5 & 3.5 \\
\hline Africa & 11.5 & 3.0 \\
\hline America, North \& Central & 117.8 & 1.2 \\
\hline America, South & 74.4 & 1.2 \\
\hline Europe & 12.4 & 5.9 \\
\hline Asia & 1.00 & 3.2 \\
\hline
\end{tabular}

Sources: Asia and pacific commission on Agriculture statistic 2010

Table.4 Average size of land holding and population density in some

Developed and developing or develop countries

\begin{tabular}{|l|l|l|}
\hline Country & Population density $(\mathbf{S q ~ k m )})$ & Average land holding \\
\hline Canada & 3.3 & 349.07 \\
\hline China & 138.6 & 0.6 \\
\hline India & 349.2 & 1.55 \\
\hline Indonesia & 123.7 & 0.87 \\
\hline Nigeria & 149.7 & 1.00 \\
\hline Spain & 80.2 & 18.79 \\
\hline USA & 31.6 & 186.95 \\
\hline
\end{tabular}

Sources: Agricultural censuses of 1990 FAO

\section{Others}

There are so many other problem like long gestation period of tree component, unavailability of good planting material and awareness, make unsuitability of Agroforestry at large scale in develop or developing country. If we talk about Jatropha, a biofuel species was grown variously by farmers of Karnataka and other parts of country but due to irregular bearing of seed and low content of oil made farmers disappointed, and now no one interested to grow particular species on their field. So there is still need of research and improvement in such type of tree species.

\section{Present status of Agroforestry in world and} India

The total area under Agroforestry in world is $1023 \mathrm{mh}$ (FAO, forest resource assessment report 2000). It is estimated that 823 million hectare area globally is under Agroforestry and silvipastoral system. Of these, 307 million hectare is Agroforestry (Nair et al., 2012).

Maximum areas of Agroforestry are found in south America (3.2 million square kilometer) followed by sub Saharan Africa that is 1.9 million square kilometer (Kumar et al., 2014). However the area under Agroforestry is increasing continuously, example in India, in 2007 it is reported 7.4 million hectare (Zomer et $a l$. , 2007) but in 2013 it reached up to 25.32 million hectare (Dhyani et al., 2013). There are several researches on Agroforestry yet too un tough in most of countries in the world. These research and technical support will facilitate the more and more expansion of particular system (Table 2). 


\section{Agroforestry potential}

The present study revealed that the land use system of Agroforestry that have vast potential and use in many aspect but, not popularized at large scale in most of countries. Study show that countries have good technical support (extension activities) and flexible legal procedure about harvesting and marketing of Agroforestry produces according to farmer's obligations, are adopt this system at large scale like Central America, Canada, Spain and Mali. Second thing the countries that have good average land holding and less population density, adopt this system very efficiently like Central America, South America, South Africa, and Canada etc. The policy of government also play important in expansion of Agroforestry area in developed continent or country like Brazil (South America continent), where government make the rule that every vehicle running across the country should have blending of $5 \%$ biofuel in diesel (Tables 3 and 4). This policy attracts farmer's attention towards Agroforestry and they tend to grow TBO'S on their field.

\section{Agroforestry promotion}

The current study revealed that there is lot of need of research and extension activities in field of agroforestry. However in recent years the national agroforestry policy, agroforestry mission and agroforestry plan is implemented by government. They may be boost up the activities of Agroforestry in India. But the thing is, there is still need of engagement of forestry professional in these policy, plan and concerned institute and increase the no. of VAN VIGHYAN KENDRA. This will definitely help in solving the question like, which tree should select? When pruning of tree would do? How to manipulate shed effect of canopy? How can reduce the below and above ground competition between tree and crop and how to harvest and market of produce. The answer of particular question will help in expansion of Agroforestry in in country. for example about Eucalyptus based Agroforestry, Eucalyptus leaf has allelopathic effect on crop but this effect can be neutralized by deep ploughing of field and continuously growing of crop every year between tree up to 4 years. The deep ploughing of field facilitates rupturing of leaves and forwards the allelopathic effect deeper inside the soil. For such type of technology can reach farmers field only through extension activities. Wood based industries should be encouraging the buyback system of marketing that encourage the farmers to grow tree on their field. The forestry specialist and government planner should be designs policy related to marketing and harvesting of these products in such a way that these policies are easily accessible and comfortable to farmers. Government of India should implement a policy of biofuel blending in diesel like other country in world (Brazil). They should made policy of blending 5\% biofuel in all vehicle running across the country. These all policy helps in conservation of our natural resources and in buildup of farmer's interest to grow tree on their field. In this consequence the forest cover will also increase and sustainability of people on Agroforestry will increased.

\section{References}

Agriculture Census. 2010-2011.

Asia and Pacific Commission on Agriculture Statistic 23rd session, Siem Reap, Cambodia 26- 30 April 2010.

Beer, J., Ibrahim, M. and Schlonvoigt, A. 2000. Timber production in tropical Agroforestry systems of Central America, Sub-plenary Sessions. XXI IUFRO World Congress, Kuala Lumpur, 1: 777-786.

Boffa, J.M. 1999. Agroforestry parklands in Sub-Saharan Africa, FAO Conserve Guide, pp 34.

Cisse, M.I. 1995. Les parcs agroforestiers au Mali.Etat des connaissanceset perspectives pourleur amélioration. AFRENA Rep., 93. ICRAF, Nairobi.

Dhyani, S.K., Handa, A.K. and Uma. 2013. Area under Agroforestry in India: An Assessment for Present Status and Future Perspective. Indian J. Agrofor., 15(1). 
Dixon, R.K. 1995. Agroforestry systems: sources or sinks for greenhouse gases? Agrofor. Systems, 31: 99-116.

FAO. 2000. Forest resources assessment report.

Gaspar, P., Mesías, F.J., Escribano, M., Rodriguez de Ledesma, A. and Pulido, F. 2007. Economic and management characterization of dehasa farms: implications for their sustainability. Agrofor. Systems, 71: 151-162.

Hoskins, M.W. 1987. Agroforestry and the social milieu. In: Steppler, H.A. and Nair. P.K.R. eds.), Agroforestry: A decade of development, pp.191-203, ICRAF. Nairobi, Kenya.

IAASTD. 2008. Agriculture at a Crossroads: Global Report. International Assessment of Agricultural Knowledge, Science, and Technology for Development. Washington DC.

Kumar, P., Singh, R.P., Singh, A.K. and Kumar, V. 2014. Quantification and distribution of agro forestry systems and practices at global level. Hort. Flora Res. Spectrum, 3(1): 1-6.

Matthews, S., S.M. Pease, A.M. Gordon, P.A. Williams. 1993. Landowner perceptions and the adoption of Agroforestry practices in southern Ontario, Canada. Agrofor. System, February 1993, Volume 21, Issue 2, pp 159-168.

Nair, P.K.R. and Garrity, D. 2012. Agroforestry-The future of global land use. Adv. Agrofor., 9: 531.

Number and area of holding and gini's index of concentration. 1990 Round of Agricultural censuses FAO.
Population data: City population. De \& CIA world fact book.

Rain Tree, J.B. and F. Torres. 1986. Agroforestry research in farming system perspective: The ICRAF Approach. ICRAF working paper.

Salil, K., Tewari. 2008. Agro-forestry Project; Dept. of Genetics and Plant Breeding College of Agriculture, G.B. Pant University of Agriculture and Technology Pantnagar - 263145, 14: 1 .

Solanki, K.R. 1998. Agroforestry research in India, The Indian J. Agri. Sci., 68: No 8.

Van Noordwijk, M. and Ong, C.K. 1999. Can the ecosystem mimic hypotheses be applied to farms in African savannahs? Agrofor. Systems, 45: 131-158.

Wending Huang, Kanninen, M., Qifen Xu, \& Baolong Huang. 1997. Agroforestry in China: Present State and Future Potential. Ambio, 26(6): 394-398.

Wibava, G., Joshi, L., Van Noordwijk, M. and Penot, E. 2006. Rubber-based Agroforestry systems (RAS) as alternatives for rubber monoculture system. IRRDB Conf. World Bank 2004.Sustaining Forest: A Development Strategy. World Bank, Washington, DC. Appendix, 2, A-3.

Zomer, R.J., Bossio, D.A., Trabucco, A., Yuanjie, L., Gupta, D.C., and Singh, V.P. 2007. "Trees and Water: Smallholder Agroforestry on Irrigated Lands in Northern India.'International Water Management Institute, Colombo, Sri Lanka (Series: IWMI Research Reports, no. 122)

Zoological Survey of India. 2012, p. 1.

\section{How to cite this article:}

Yogesh Kumar, Tarun Kumar Thakur and Thakur, A. 2017. Socio-Cultural Paradigm of Agroforestry in India. Int.J.Curr.Microbiol.App.Sci. 6(6): 1371-1377.

doi: https://doi.org/10.20546/ijcmas.2017.606.161 